\begin{tabular}{|c|l|}
\hline Title & $\begin{array}{l}\text { Combined neutralization-adsorption system for the disposal of hydrothermally altered excavated rock producing acidic } \\
\text { leachate with hazardous elements }\end{array}$ \\
\hline Author(s) & Tatsuhara, Takeshi; A rima, Takahiko; Igarashi, Toshifumi; Tabelin, Carlito Baltazar \\
\hline Citation & $\begin{array}{l}\text { Engineering Geology, 139-140, 76-84 } \\
\text { https://doi.org/10.1016/.enggeo.2012.04.006 }\end{array}$ \\
\hline Issue Date & 2012-06-22 \\
\hline Doc URL & http://hdl.handle.net/2115/49832 \\
\hline Type & article(author version) \\
\hline File Information & EG139-140_76-84.pdf \\
\hline
\end{tabular}

Instructions for use 


\title{
Combined neutralization-adsorption system for the disposal of hydrothermally altered excavated rock producing acidic leachate with hazardous elements
}

\author{
Takeshi Tatsuhara ${ }^{1}$, Takahiko Arima ${ }^{2}$, Toshifumi Igarashi ${ }^{3}$ and Carlito Baltazar Tabelin ${ }^{4}$ \\ ${ }^{1}$ Pacific Consultants Co., Ltd., Tokyo 163-0730, JAPAN \\ ${ }^{2}$ Nippon Koei Co., Ltd., Tokyo 102-0083, JAPAN \\ ${ }^{3}$ Laboratory of Groundwater and Mass Transport, Faculty of Engineering, Hokkaido University, Sapporo 060- \\ 8608, JAPAN \\ ${ }^{4}$ Laboratory of Soil Environment Engineering, Faculty of Engineering, Hokkaido University, Sapporo 060-8608, \\ JAPAN
}

Emails: takeshi.tatsuhara@tk.pacific.co.jp, a7139@n-koei.co.jp, tosifumi@eng.hokudai.ac.jp and carlito@transer.eng.hokudai.ac.jp

\begin{abstract}
Hydrothermally altered rock excavated in a tunnel project produces acidic leachate containing hazardous elements that include arsenic $(\mathrm{As})$, lead $(\mathrm{Pb})$, copper $(\mathrm{Cu})$ and zinc $(\mathrm{Zn})$. To mitigate this problem, this paper evaluated a combined neutralization-adsorption system that used readily available and cheap reagents like calcium carbonate $\left(\mathrm{CaCO}_{3}\right)$ and partly-weathered volcanic ash. Batch neutralization experiments showed that $\mathrm{CaCO}_{3}$ was effective in raising the $\mathrm{pH}$ of the leachate around neutral while the batch adsorption experiments illustrated that the volcanic ash sample collected near the tunnel project area was highly capable of adsorbing arsenate $(\mathrm{As}[\mathrm{V}]), \mathrm{Pb}, \mathrm{Cu}$ and $\mathrm{Zn}$. Under column conditions, the amount of hazardous elements released from the rock increased by several folds and their breakthrough curves had flushing-out trends. The mechanisms of As and heavy metals release probably include the dissolution of soluble phases and pyrite oxidation. Addition of $\mathrm{CaCO}_{3}$ in the column experiments based on estimates from the batch results underestimated the amount of neutralizer needed to adjust the effluent $\mathrm{pH}$ to around 8 , resulting only in slight increase of the $\mathrm{pH}$. Nevertheless, the presence of $\mathrm{CaCO}_{3}$ drastically reduced the amount of hazardous elements released from the altered rock especially during the initial stages of the column experiments. Combining neutralization and adsorption effectively reduced the amount of As and heavy metals in the effluent throughout the duration of the column experiments, which is attributed to the slight neutralizing effect of volcanic ash that raised the $\mathrm{pH}$ around circumneutral as well as its rich $\mathrm{Al}$ and $\mathrm{Fe}$ oxyhydroxide/oxide contents. The combined system immobilized the hazardous elements through a combination of co-precipitation and adsorption reactions and showed potential as an alternative method for the disposal of altered rocks producing acidic leachate.
\end{abstract}

Keywords: hydrothermally altered rock, arsenic, heavy metals, neutralization, adsorption

\footnotetext{
*Corresponding author: Tel: +81-11-706-6311 Fax: +81-11-706-6308

email: carlito@ trans-er.eng.hokudai.ac.jp
} 


\section{INTRODUCTION}

Hydrothermally altered rocks, which are widely distributed in geologically active volcanic regions like Japan, are formed due to the migration of superheated fluid/water called hydrothermal solutions through fractures and fissures in rocks. Enrichment of these rocks with toxic elements like $\mathrm{Pb}$ and As preferentially occurs in and around precipitated pyrite grains, which are oxidized upon exposure to the atmosphere producing acidic leachate containing these toxic elements (Igarashi et al., 2008; Tabelin and Igarashi, 2009). Tunnels for roads, railways and other projects in the island of Hokkaido have excavated these kinds of rocks, which are potential sources of soil and groundwater contamination. At the moment, excavated altered rocks are being disposed of by applying landfill liners to prevent the interaction of the rock and rainwater similar to those utilized in the disposal of municipal and industrial wastes (Katsumi et al., 2001; Lundgren and Soderblom, 1985; Malusis et al., 2003; Rapti-Caputo et al., 2006; Wijeyesekera et al., 2001), but this method is very expensive and impractical so that alternative methods are being explored.

Leaching of $\mathrm{As}$ and $\mathrm{Pb}$ from altered rocks and their mechanisms of release are both strongly pH dependent (Tabelin and Igarashi, 2009; Tabelin et al., 2012a). In addition, minor and trace minerals that have strong effects on the $\mathrm{pH}$ of the rock when in contact with water (e.g., calcite and pyrite) are important in the mobilization of these hazardous elements (Tabelin et al., 2010, 2012a,b). The best way to immobilize As and Pb from altered rocks is through adsorption and precipitation, respectively, and these processes are most effective in the circumneutral pH range (Tabelin and Igarashi, 2009; Tabelin et al., 2010; Tabelin et al., 2012a). Based on these previous studies, we have developed a disposal method called the neutralization-adsorption system as a simple and low cost alternative to special landfilling. The principles behind this system are simple: identify the mechanisms of As and heavy metal release from the altered rock, minimize the extent of these mechanisms, and provide 
additional countermeasures to immobilize any hazardous element released from the rock. In contrast to traditional landfills that prevent the interaction of wastes with water through the use of special barriers, the concept of this system more closely resembles a permeable reactive barrier (PRB). In this proposed system, water is allowed to percolate into the waste, albeit at a lower infiltration rate, and the "loaded" leachate would then pass through the adsorption layer where immobilization of the hazardous elements would take place. A conceptual model of this new neutralization-adsorption system is presented in Figure 1.

The Teine mine area, which is located northwest of Sapporo, Hokkaido, Japan, consists of Late Miocene andessite tuff breccia and mudstone, extruded by altered andesite (propylite). The veins occur mainly in altered andesite, which are grouped into Mitsuyama, Koganezawa and Bannozawa (Imai, 1999). The mine produced gold (Au), silver (Ag) and copper $(\mathrm{Cu})$ from 1893 until 1971 (Imai, 1978; Sugimoto, 1952; Watanabe, 1936; Watanabe 1943; Watanabe 1944). A new tunnel was constructed near the Mitsuyama deposit in 2006 to collect acid mine drainage for the new water treatment system installed in this mine. The construction of this new tunnel excavated hydrothermally altered rock rich in hazardous elements like $\mathrm{As}, \mathrm{Pb}, \mathrm{Cu}$ and $\mathrm{Zn}$.

The main goal of this study is to evaluate the effectiveness of the neutralization-adsorption system in the immobilization of toxic elements like As and heavy metals such as $\mathrm{Pb}, \mathrm{Cu}$ and $\mathrm{Zn}$. The neutralizer and adsorbent selected for our experiments are calcium carbonate $\left(\mathrm{CaCO}_{3}\right)$ and partly-weathered volcanic ash, respectively. To achieve our goal, we first evaluated the effects of $\mathrm{CaCO}_{3}$ on the leachate chemistry through batch neutralization experiments. Second, batch adsorption experiments using the ash sample with high amorphous aluminum (Al) and iron (Fe) mineral contents were carried out to characterize its adsorption capacity and affinity for $\mathrm{As}, \mathrm{Pb}, \mathrm{Cu}$ and $\mathrm{Zn}$. Finally, column experiments were conducted using different neutralization and adsorption configurations to compare the effects 
of using neutralization only and a combined neutralization-adsorption system. If this alternative disposal system is effective, it could provide a more economical, practical and safe way of disposing these hazardous excavated rocks.

\section{MATERIALS AND METHODS}

\subsection{Hydrothermally altered rock, volcanic ash and calcium carbonate}

The hydrothermally altered rock sample used in this study was collected from the bulk excavated rock stored in an interim disposal site that had already been exposed to the atmosphere for ca. 6 months. This interim disposal site is used until the final disposal of the rock and/or while waiting for the thawing of snow in winter. The test material (i.e., partlyoxidized altered rock) was selected because it would most likely represent the actual waste rock for disposal. The rock sample was air dried, crushed and sieved using a $2 \mathrm{~mm}$ aperture screen. The partly-weathered volcanic ash sample was collected around the tunnel area. Volcanic ash was selected as an ideal adsorbent because it is inexpensive and widespread in Hokkaido. Furthermore, volcanic ash has been shown as an effective adsorbent of hazardous elements, such as As and heavy metals, because of the presence of amorphous and crystalline Al and Fe oxyhydroxide/oxide phases (Dixit and Hering, 2003; Toscano et al., 2008). The volcanic ash sample was also air dried and sieved using a $2 \mathrm{~mm}$ aperture screen. In preparation for the chemical and mineralogical analyses, the rock and ash samples were further ground to $<50 \mu \mathrm{m}$. Chemical analysis of the samples was carried out using an X-ray fluorescence spectrometer, Spectro Xepos (Rigaku Corporation, Japan), while their mineralogical composition was determined utilizing an X-ray diffractometer, MultiFlex (Rigaku Corporation, Japan). Both analyses were done using pressed powders of the samples. Amorphous $\mathrm{Al}$ and $\mathrm{Fe}$ phases in the ash, which are important in the adsorption of As and heavy metals, were determined using acidic oxalate solution extraction. Calcium carbonate 
was selected as the neutralizer of the acidic leachate because it is also inexpensive and widely used in the treatment of acid mine drainage.

\subsection{Batch leaching, neutralization and adsorption experiments}

Batch leaching experiments were carried out by mixing 15 grams of the crushed rock sample and $150 \mathrm{~mL}$ of deionized water at $120 \mathrm{rpm}$ for 24 hours. A similar procedure was used for the neutralization experiments; the only difference was the addition of $\mathrm{CaCO}_{3}$ (analytical grade powder) ranging from 0.5 to $25 \%$ of the weight of the rock sample used. After shaking, the $\mathrm{pH}$ values of the leachates were measured, and then the leachates were filtered through 0.45 $\mu \mathrm{m}$ Millex ${ }^{\circledR}$ cellulose acetate membrane filters (Millipore Corporation, USA). The filtrates were acidified using hydrochloric acid $(\mathrm{HCl})$ prior to the chemical analysis. The degree of concentration reduction of important metallic and metalloid species in the leachate was described as residual percentages. These values were calculated using the following equation:

$$
\% \text { residual }=\frac{C_{0}-C}{C_{0}} \times 100
$$

where, \% residual is the residual percentage $(\%), C_{0}$ is the initial concentration prior to neutralization $(\mathrm{mg} / \mathrm{L})$, and $C$ is the concentration after neutralization $(\mathrm{mg} / \mathrm{L})$.

The batch adsorption experiments were done to characterize the adsorption properties of the volcanic ash sample for $\mathrm{As}[\mathrm{V}], \mathrm{Cu}, \mathrm{Pb}$ and $\mathrm{Zn}$. The ash was added in various amounts to solutions with known $\mathrm{As}[\mathrm{V}], \mathrm{Cu}, \mathrm{Pb}$, or $\mathrm{Zn}$ concentration prepared from reagent grade standard solutions. The mixtures were then shaken at $120 \mathrm{rpm}$ for 24 hours. Leachates were then filtered through $0.45 \mu \mathrm{m}$ Millex ${ }^{\circledR}$ filters prior to the chemical analyses. Adsorption isotherms were obtained using the following equation:

$$
q=\frac{\left(C_{0}-C\right) \cdot V}{W}
$$


where, $q$ is the adsorbed amount $(\mathrm{mg} / \mathrm{g}), C_{0}$ is the initial concentration $(\mathrm{mg} / \mathrm{L}), C$ is the equilibrium concentration (mg/L), $V$ is the volume of solution (L), and $W$ is the amount of the ash sample added (g).

\subsection{Column experiments}

The columns used are made of acrylic tubes mounted on steel stands with each stand accommodating three columns. The columns have heights of $350 \mathrm{~mm}$ and inner diameters of $52 \mathrm{~mm}$. Covers were also designed with small perforated holes to simulate rain and protect the columns from outside contaminants and dusts. A schematic diagram and details of the column dimensions are shown in Figure 2.

Five columns were constructed and details of their initial conditions are listed in Table 1. For standardization, the rock layer (with or without $\mathrm{CaCO}_{3}$ ) and ash layer were compacted to have bulk densities of 1.83 and $0.77 \mathrm{~g} / \mathrm{cm}^{3}$, respectively. The neutralizer was mixed thoroughly with the altered rock prior to the construction of rock layers with neutralization. Fifty milliliters of deionized water $(18 \mathrm{M} \Omega \cdot \mathrm{cm})$ was poured into each column once a week through the rainfall simulator. This amount corresponds to a weekly precipitation of $23.5 \mathrm{~mm}$, which is roughly equivalent to the average weekly rainfall in Sapporo. Deionized water was allowed to infiltrate by gravity to simulate the water movement at conditions close to the actual field setting. After ca. 2 days, effluents were collected, filtered through $0.45 \mu \mathrm{m}$ Millex ${ }^{\circledR}$ filters, acidified using $\mathrm{HCl}$ and analyzed.

For the remainder of this paper, the columns are referred to by the following notations:

- column composed of the altered rock only is called case $\mathrm{R}$,

- columns with neutralizer added are called cases $\mathrm{R}+\mathrm{N} 1$ and $\mathrm{R}+\mathrm{N} 2$ for $1 \%$ and $2 \%$ $\mathrm{CaCO}_{3}$, respectively, 
- columns with both neutralizer and adsorption layer are referred to as cases $\mathrm{R}+\mathrm{N} 1+\mathrm{A}$ and $\mathrm{R}+\mathrm{N} 2+\mathrm{A}$ corresponding to $1 \% \mathrm{CaCO}_{3}+2 \mathrm{~cm}$ thick ash layer and $2 \% \mathrm{CaCO}_{3}+2$ $\mathrm{cm}$ thick ash layer, respectively.

In addition, "leachate" will be used to denote liquid samples from batch experiments while samples collected in the columns will be called "effluent".

\subsection{Chemical analysis}

Concentrations of $\mathrm{As}, \mathrm{Cu}, \mathrm{Pb}, \mathrm{Zn}$ and coexisting ions greater than $0.1 \mathrm{mg} / \mathrm{L}$ were analyzed using an inductively coupled plasma atomic emission spectrometer (ICP-AES) (ICPE - 9000, Shimadzu Corporation, Japan). Arsenic concentrations less than $0.1 \mathrm{mg} / \mathrm{L}$ were analyzed using a hydride generation attachment coupled with the ICP-AES. In preparation for the hydride generation analysis, $30 \mathrm{ml}$ of leachate or effluent was mixed with $15 \mathrm{ml}$ of $12 \mathrm{M} \mathrm{HCl}$, $2 \mathrm{ml}$ of $20 \%$ potassium iodide (KI) solution and $1 \mathrm{ml}$ of $10 \%$ ascorbic acid solution, and then diluted with deionized water to $50 \mathrm{ml}$. All chemicals used in the preparation and analysis were reagent grade. Low $\mathrm{Cu}, \mathrm{Pb}$ and $\mathrm{Zn}$ concentrations $(<0.1 \mathrm{mg} / \mathrm{L})$ were determined using an ultrasonic aerosol generator attachment coupled with the ICP-AES. The standard ICP-AES method (i.e., without attachments) used has a margin of error of ca. $2-3 \%$ whereas the more sensitive hydride generation and ultrasonic aerosol generator methods have uncertainties of ca. $5 \%$.

\subsection{Geochemical modeling}

The saturation indices $(S I)$ of $\mathrm{Al}$ and Fe oxides, oxyhydroxides and hydroxides were calculated from the measured leachate and effluent chemistries using PHREEQC (Parkhurst and Appelo, 1999) with the THERMODEM database compiled by the French Geological Survey (BRGM Institute). These thermodynamic calculations could provide additional insights into the processes controlling the mobilization and immobilization of the hazardous elements in our system. 


\section{RESULTS}

\subsection{Properties of the altered rock and volcanic ash}

The chemical and mineralogical compositions of the altered rock and partly-weathered volcanic ash used in this study are listed in Tables 2 and 3, respectively. The altered rock sample contains significant amounts of $\mathrm{S}$ at $10.6 \mathrm{wt} \%$, which could be attributed to the presence of pyrite. It also has significant $\mathrm{As}, \mathrm{Pb}, \mathrm{Cu}$ and $\mathrm{Zn}$ contents at 150, 375, 68 and 62 $\mathrm{mg} / \mathrm{kg}$, respectively. Results of the leaching experiment of the altered rock sample using deionized water illustrated that its $\mathrm{pH}$ was acidic and it released significant amounts of $\mathrm{As}, \mathrm{Pb}$, $\mathrm{Cu}$ and $\mathrm{Zn}$ (Table 4). The leaching results also showed relatively high concentrations of $\mathrm{Fe}$ and $\mathrm{SO}_{4}{ }^{2-}$, which suggests that dissolution of soluble secondary minerals and oxidation of pyrite both occurred. The ash sample used as adsorbent is composed mostly of quartz, anorthite and chlorite, and is rich in $\mathrm{Al}$ and Fe bearing minerals (Tables 2 and 3). It also has significant amorphous $\mathrm{Al}$ and $\mathrm{Fe}$ contents at 24 and $13.6 \mathrm{mg} / \mathrm{g}$, respectively, indicating that this ash sample is a potentially strong adsorbent of As and heavy metals.

\subsection{Batch neutralization and adsorption experiments}

Figure 3 illustrates the $\mathrm{pH}$ variation of the leachate as a function of the amount of neutralizer added to the altered rock. The leachate $\mathrm{pH}$ was initially acidic at 2.6 and addition of only $2.5 \%$ $\mathrm{CaCO}_{3}(3.75 \mathrm{~g})$ effectively increased the $\mathrm{pH}$ around neutral. Once the neutral $\mathrm{pH}$ range was reached, higher $\mathrm{CaCO}_{3}$ addition had no significant effect on the $\mathrm{pH}$ of the leachate. The reduction in the concentrations of dissolved hazardous elements like $\mathrm{As}, \mathrm{Cu}, \mathrm{Pb}$ and $\mathrm{Zn}$ as well as major metallic species, such as $\mathrm{Al}$ and $\mathrm{Fe}$ as a function of $\mathrm{pH}$ are presented in Figures 4 and 5, respectively. The \% residual of the hazardous elements decreased with increasing $\mathrm{pH}$ of the leachate. When the $\mathrm{pH}$ of the leachate increased to about 4 , the $\%$ residual dropped to around $50 \%$. Increasing the $\mathrm{pH}$ until up to the neutral range effectively lowered the $\%$ 
residual to almost zero. Similarly, the high concentrations of $\mathrm{Al}$ and $\mathrm{Fe}(\mathrm{Al}: 70.8 \mathrm{mg} / \mathrm{L} ; \mathrm{Fe}$ : $378 \mathrm{mg} / \mathrm{L}$ ) decreased to less than $1 \mathrm{mg} / \mathrm{L}$ after neutralization.

Calculated saturation indices $(\mathrm{SI})$ of gibbsite $\left(\mathrm{Al}(\mathrm{OH})_{3}\right)$, diaspore $(\mathrm{AlOOH}), \mathrm{Fe}(\mathrm{OH})_{3}$ and goethite $(\mathrm{FeOOH})$ as well as those of malachite $\left(\mathrm{Cu}_{2}(\mathrm{OH})_{2} \mathrm{CO}_{3}\right)$, smithsonite $\left(\mathrm{ZnCO}_{3}\right)$, hydrocerrusite $\left(\mathrm{Pb}_{3}\left(\mathrm{CO}_{2}\right)_{3}(\mathrm{OH})_{2}\right)$ and $\mathrm{Pb}(\mathrm{OH})_{2}$ in the leachate are shown in Figure 6. Our results show that only $\mathrm{Cu}$ is predicted to precipitate as malachite due to the addition of the neutralizer while $\mathrm{Pb}$, As and $\mathrm{Zn}$ remain dissolved in solution. Also, the precipitation of both $\mathrm{Al}$ and Fe-oxyhydroxides/oxides are thermodynamically possible at $\mathrm{pH}>4$.

The sorption behaviors of $\mathrm{As}[\mathrm{V}], \mathrm{Cu}, \mathrm{Pb}$, and $\mathrm{Zn}$ onto volcanic ash and the corresponding Freundlich isotherms of best fit are shown in Figure 7. The partition coefficients $\left(K_{F}\right)$ (i.e., ratio of adsorbed amount $q$ to liquid-phase equilibrium concentration $C$ ) for $\mathrm{As}[\mathrm{V}], \mathrm{Pb}, \mathrm{Cu}$ and $\mathrm{Zn}$ are equal to $1.87,0.37,0.13$ and $0.07 \mathrm{mg} / \mathrm{g}$, respectively at $C$ equal to $1 \mathrm{mg} / \mathrm{L}$. These results indicate that the volcanic ash sample is capable of adsorbing $\mathrm{As}[\mathrm{V}], \mathrm{Pb}, \mathrm{Cu}$ and $\mathrm{Zn}$. Also, the values of $K_{F}$ indicate that the ash sample has the highest adsorption affinity for $\mathrm{As}[\mathrm{V}]$, followed by $\mathrm{Pb}, \mathrm{Cu}$ and least for $\mathrm{Zn}$.

\subsection{Column experiments}

\subsection{1 $\mathrm{pH}$ change and breakthrough curves of $\mathrm{As}, \mathrm{Pb}, \mathrm{Cu}, \mathrm{Zn}, \mathrm{Fe}, \mathrm{Al}$ and $\mathrm{SO}_{4}{ }^{2-}$}

The column experiments lasted for 24 weeks and the evolution of the effluent chemistry is illustrated in Figure 8. The $\mathrm{pH}$ of case $\mathrm{R}$ (i.e., rock only column) was strongly acidic throughout the duration of the experiment. The first effluent collected after 4 weeks had a $\mathrm{pH}$ value of 1.7 , increased to ca. $\mathrm{pH} 3$ and then stabilized in the range of $2-3$. Addition of $1 \%$ $\mathrm{CaCO}_{3}$ (case $\mathrm{R}+\mathrm{N} 1$ ) did not have significant effects on the $\mathrm{pH}$ while doubling this amount of neutralizer added (case $\mathrm{R}+\mathrm{N} 2$ ) only resulted in a slight increase of the $\mathrm{pH}$. The combined neutralization-adsorption columns had the highest $\mathrm{pH}$ increase and approached the $6-7$ range for case $\mathrm{R}+\mathrm{N} 2+\mathrm{A}$ (Figure $8(\mathrm{a})$ ). 
The leaching curve of As had a "flushing-out" trend especially in case R as illustrated in Figure 8(b). The initial concentration of As in the effluent was $134 \mathrm{mg} / \mathrm{L}$, which dropped to $0.11 \mathrm{mg} / \mathrm{L}$ after only three weeks. After this rapid decrease, the concentration of As in the effluent stabilized in the range of $0.02-0.5 \mathrm{mg} / \mathrm{L}$. The addition of $1 \% \mathrm{CaCO}_{3}$ had little effect on the $\mathrm{pH}$, but dramatically decreased the concentration of As in the effluent. Increasing the amount of neutralizer to $2 \%$ further reduced the concentration of As in the effluent to below $0.01 \mathrm{mg} / \mathrm{L}$. Combining neutralization and adsorption had the best results in terms of the immobilization of As (Figure 8(b)). The concentrations of As in the effluent collected from the combined system were less than the detection limit of the ICP-AES + hydride generation $(<0.001 \mathrm{mg} / \mathrm{L})$ regardless of the amount of neutralizer added.

The leaching behavior of heavy metals $\mathrm{Pb}, \mathrm{Cu}$ and $\mathrm{Zn}$ was similar to As and also had "flushing-out" trends as illustrated in Figures 8(c), (d) and (e). The initial concentrations of these heavy metals in the effluent were very high $(70-200 \mathrm{mg} / \mathrm{L})$, decreased rapidly and stabilized in the concentration range of $0.02-0.1 \mathrm{mg} / \mathrm{L}$. The leaching behaviors of these heavy metals were also affected in similar fashions by the addition of neutralizer and adsorbent (Figures 8(c), (d) and (e)). The initial concentrations of $\mathrm{Pb}, \mathrm{Cu}$ and $\mathrm{Zn}$ were reduced by ca. $80 \%, 70 \%$ and $30 \%$, respectively after the addition of the neutralizer (cases $\mathrm{R}+\mathrm{N} 1$ and $\mathrm{R}+\mathrm{N} 2$ ). However, after this initial dramatic reduction, the leaching trends of heavy metals in the effluents decreased gradually with time, and their concentrations were higher than those collected in the column composed of the altered rock only. Immobilization of the heavy metals was more pronounced when a combined neutralization-adsorption system was employed as shown in Figures 8(c), (d) and (e). Using this system, the "flushing-out" leaching trends of $\mathrm{Pb}, \mathrm{Cu}$ and $\mathrm{Zn}$ disappeared and more linear leaching curves with time were observed (cases $\mathrm{R}+\mathrm{N} 1+\mathrm{A}$ and $\mathrm{R}+\mathrm{N} 2+\mathrm{A}$ ). Also, the addition of an adsorption layer effectively 
reduced the concentration of $\mathrm{Zn}$ in the effluent to $<0.1 \mathrm{mg} / \mathrm{L}$, which was not achieved by employing neutralization alone (Figure 8(e)).

The leaching behaviors of $\mathrm{Fe}$ and $\mathrm{Al}$ were similar to those of $\mathrm{Pb}, \mathrm{Cu}$ and $\mathrm{Zn}$, that is, "flushing-out" trends were observed only in columns composed of the altered rock only and those with neutralization while more linear leaching curves appeared in columns with both neutralization and adsorption (Figures 8(f) and (g)). Figure 8(h) shows that the leaching curve of $\mathrm{SO}_{4}{ }^{2-}$ with time also had a "flushing-out" trend similar to As and the heavy metals especially in the column composed of the altered rock only. Addition of $\mathrm{CaCO}_{3}$ resulted in a more gradual decrease of $\mathrm{SO}_{4}{ }^{2-}$ with time while a combined neutralization-adsorption system resulted in a more linear leaching curve. Also, the $\mathrm{SO}_{4}{ }^{2-}$ concentrations in all cases were close to each other after ca. 22 weeks, which suggests apparent equilibrium.

Mass balances of $\mathrm{As}, \mathrm{Pb}, \mathrm{Cu}, \mathrm{Zn}, \mathrm{Al}$ and $\mathrm{Fe}$ in case $\mathrm{R}+\mathrm{N} 2+\mathrm{A}$ were calculated to estimate the amount of hazardous elements immobilized due to neutralization and adsorption (Table 5). The results showed that immobilization of $\mathrm{As}, \mathrm{Pb}$ and $\mathrm{Cu}$ occurred mainly because of neutralization that retained ca. 99,73 and $80 \%$ of the total mass released from the rock, respectively. In contrast, neutralization only retained ca. $24 \%$ of the total mass of $\mathrm{Zn}$ released from the rock. Furthermore, the adsorption layer reduced the amount of all hazardous elements released from the rock except As, the majority of which was already immobilized after neutralization. The amount of $\mathrm{Al}$ and Fe released from the rock also decreased dramatically because of the addition of neutralizer and adsorbent, which had strong positive effect on the immobilization of the hazardous elements via co-precipitation and adsorption reactions (Table 5; Figure 8).

3.3.2 Correlations of $\mathrm{pH}, \mathrm{As}, \mathrm{Pb}, \mathrm{Cu}, \mathrm{Zn}$ and $\mathrm{Fe}$ with $\mathrm{SO}_{4}{ }^{2-}$, and related geochemical modeling calculations 
Figure 9(a) illustrates the correlations of $\mathrm{SO}_{4}{ }^{2-}$ with $\mathrm{pH}$ in all cases. There is a negative correlation between these two parameters, indicating that higher $\mathrm{SO}_{4}{ }^{2-}$ concentrations mean lower $\mathrm{pH}$ values, and that the acidic $\mathrm{pH}$ produced by the altered rock is associated with processes that release $\mathrm{SO}_{4}{ }^{2-}$ like dissolution of soluble Fe-sulfates and oxidation of pyrite. In contrast, the correlations of $\mathrm{SO}_{4}{ }^{2-}$ with $\mathrm{As}, \mathrm{Pb}, \mathrm{Cu}, \mathrm{Zn}$ and $\mathrm{Fe}$ were all strongly positive, which suggests that the leaching of $\mathrm{SO}_{4}{ }^{2-}$ occurs in conjunction with the mobilization of these elements (Figures 9(b), (c), (d), (e) and (f)).

The calculated SIs with time for cases $\mathrm{R}, \mathrm{R}+\mathrm{N} 2$ and $\mathrm{R}+\mathrm{N} 2+\mathrm{A}$ are presented in Figure 10. In the column composed of the altered rock only (case R), SI values of most $\mathrm{Al}$ and $\mathrm{Fe}$ oxyhydroxides/oxides except goethite $(\mathrm{FeOOH})$ were less than zero, indicating that the precipitation of these minerals that are important in the immobilization of As and the heavy metals are not thermodynamically favorable. Also, exceptionally high concentrations of $\mathrm{Pb}$, $\mathrm{SO}_{4}{ }^{2-}$ and $\mathrm{Ca}^{2+}$ at the start of the experiments probably resulted in the precipitation of anglesite $\left(\mathrm{PbSO}_{4}\right)$ and gypsum $\left(\mathrm{CaSO}_{4} \cdot 2 \mathrm{H}_{2} \mathrm{O}\right)$ (Figure $\left.10(\mathrm{a})\right)$. Solubility of $\mathrm{PbSO}_{4}$ is relatively low, but gypsum could rapidly dissolve with time because of its generally high solubility. Addition of the neutralizer raised the $S I$ values of $\mathrm{Al}$ and $\mathrm{Fe}$ oxyhydroxides/oxides close to saturation, but only diaspore $(\mathrm{AlOOH})$ and goethite $(\mathrm{FeOOH})$ are predicted to precipitate (Figure 10(b)). In columns with both neutralizer and adsorbent, the $S I$ values of most $\mathrm{Al}$ and $\mathrm{Fe}$ oxyhydroxides/oxides were above zero, which suggests that the precipitation of these minerals is thermodynamically favorable (Figure 10(c)). Anglesite is also predicted to precipitate at the start of the experiment while gypsum is expected to precipitate in cases $\mathrm{R}+\mathrm{N} 2$ and $\mathrm{R}+\mathrm{N} 2+\mathrm{A}$ after week 4.

\section{DISCUSSION}

\subsection{Dissolution of soluble phases and pyrite oxidation}


Exposure of pyrite to the atmosphere results in its rapid oxidation commencing with the oxidation of $\mathrm{S}^{2-}$ species (Schaufuss et al., 1998). This process is further enhanced in the presence of water or moisture that could strip reaction products exposing new sites on the pyrite surface. Reaction products from the atmospheric oxidation of pyrite include $\mathrm{Fe}$-sulfates, Fe oxyhydroxides and oxides, which are more soluble than pyrite especially under acidic conditions (De donato et al., 1993; Schaufuss et al., 1998; Todd et al., 2003). Because the altered rock sample used in this study was already exposed to the atmosphere and rain prior to sampling, it contains significant amounts of these soluble phases. The dissolution of these soluble phases was particularly evident in the breakthrough curves of $\mathrm{SO}_{4}{ }^{2-}$ and $\mathrm{Fe}$ in the column composed only of the altered rock especially around the first 8 weeks (case R; Figure 8). These results suggest that the impact of the dissolution of soluble phases on acid production and mobilization of the hazardous elements is more pronounced at the start of the column experiments and significantly decreases with time. Mobilizations of $\mathrm{As}, \mathrm{Pb}, \mathrm{Cu}$ and $\mathrm{Zn}$ from the altered rock were also closely related to the dissolution of these soluble phases as suggested by their similar breakthrough curves to those of $\mathrm{Fe}$ and $\mathrm{SO}_{4}{ }^{2-}$ as well as their strong positive correlations with $\mathrm{Fe}$ and $\mathrm{SO}_{4}{ }^{2-}$ (Figure 8(f)). After the dissolution of most of these soluble phases, acidic leachate containing these hazardous elements persisted because of the continued oxidation of pyrite. This long-term acid production due to pyrite oxidation can be explained by the following chemical reactions:

$$
\begin{aligned}
& \mathrm{FeS}_{2(\mathrm{~s})}+3.5 \mathrm{O}_{2(\mathrm{aq})}+\mathrm{H}_{2} \mathrm{O} \longrightarrow \mathrm{Fe}^{2+}+2 \mathrm{H}^{+}+2 \mathrm{SO}_{4}{ }^{2-} \\
& \mathrm{Fe}^{2+}+0.25 \mathrm{O}_{2(\mathrm{aq})}+\mathrm{H}^{+} \longrightarrow \mathrm{Fe}^{3+}+0.5 \mathrm{H}_{2} \mathrm{O} \\
& \mathrm{FeS}_{2(\mathrm{~s})}+14 \mathrm{Fe}^{3+}+8 \mathrm{H}_{2} \mathrm{O} \longrightarrow 15 \mathrm{Fe}^{2+}+2 \mathrm{SO}_{4}{ }^{2-}+16 \mathrm{H}^{+}
\end{aligned}
$$

Ferric ions $\left(\mathrm{Fe}^{3+}\right)$ and $\mathrm{O}_{2}$ are two of the most important oxidants of pyrite (Holmes and Crundwell, 2000; McKibben and Barnes, 1986; Moses et al., 1987; Moses and Herman, 1991; Nicholson et al., 1988). Oxygen further acts as an oxidant of $\mathrm{Fe}^{2+}$ to form $\mathrm{Fe}^{3+}$ as shown in 
equation (4). These equations also explain that oxidation of 1 mole of pyrite could produce ca. $2-16$ moles of $\mathrm{H}^{+}$. Based on these results, the dominant release mechanisms of these hazardous elements include the dissolution of soluble phases and pyrite oxidation consistent with our previously published works (Tabelin and Igarashi, 2009; Tabelin et al., 2012a,b).

\subsection{Neutralization, precipitation and adsorption}

The alternative disposal system proposed in this study focused on the retardation of acid dissolution and pyrite oxidation, which are the dominant release mechanisms of $\mathrm{As}, \mathrm{Pb}, \mathrm{Cu}$ and $\mathrm{Zn}$ in acidic/pyritic altered rocks. Addition of $\mathrm{CaCO}_{3}$ effectively raised the $\mathrm{pH}$ close to neutral that resulted in lower concentrations of $\mathrm{As}, \mathrm{Pb}, \mathrm{Cu}$ and $\mathrm{Zn}$ in the batch tests (Figure 4). However, using a similar ratio of $\mathrm{CaCO}_{3}(2 \%)$ in the column experiments did not have the same strong neutralizing effect on the effluent (Figure 8). These results suggest that batch neutralization tests underestimate the required amount of neutralizer. This difference could be attributed to the constant "renewal" of the pore water in the column experiments that probably results in more localized disequilibrium conditions. Results of the column experiments further showed that the addition of small amounts of neutralizer dramatically reduced the concentration of As in the effluent throughout the experiments, but not the heavy metals (Figure 8). The higher immobilization of As in comparison to the heavy metals could be attributed to its strong adsorption affinity to $\mathrm{Al}$ and $\mathrm{Fe}$ oxyhydroxide/oxide precipitates (Cornelis et al., 2008; Dousova et al., 2003; Dzombak and Morel, 1990; Gosh and Teoh, 1985; Lin and Puls, 2000; Wang and Mulligan, 2006). The similar leaching trends of $\mathrm{Pb}, \mathrm{Cu}$ and $\mathrm{Zn}$ to those of $\mathrm{Al}, \mathrm{Fe}$ and $\mathrm{SO}_{4}{ }^{2-}$ suggest that the addition of $\mathrm{CaCO}_{3}$ may affect the dissolution of soluble phases available in the rock. The $\mathrm{CaCO}_{3}$ addition probably slowed down the dissolution of these soluble phases, resulting in the observed gradual decreasing trend and the higher concentrations of these heavy metals in comparison to the column composed of the rock only. Furthermore, our modeling calculations predict that because the 
$\mathrm{pH}$ was not raised high enough, precipitations of $\mathrm{Al}$ and Fe oxyhydroxides/oxides, which are important in the immobilization of As and the heavy metals, were greatly limited (Figures 8 and 10). None the less, neutralization effectively lowered the concentrations of $\mathrm{As}, \mathrm{Pb}, \mathrm{Cu}$ and $\mathrm{Zn}$ in the column effluents especially during the first couple of weeks when very high concentrations of these toxic elements were observed in the effluent of the column composed of the altered rock only. Among the heavy metals, $\mathrm{Pb}$ is predicted to directly precipitate as anglesite $\left(\mathrm{PbSO}_{4}\right)$, which is relatively insoluble and could act as an important sink of dissolved $\mathrm{Pb}$ (Figure 10(b)). In contrast, direct precipitations of $\mathrm{As}, \mathrm{Cu}$ and $\mathrm{Zn}$ either as sulfates, carbonates or oxyhydroxides were thermodynamically unfavorable. Thus, the observed decrease in the concentration of these hazardous elements in the effluent could be attributed to their co-precipitation and/or adsorption with and/or onto $\mathrm{Al}$ and $\mathrm{Fe}$ oxyhydroxides/oxides (Figures 8 and 10).

We achieved the best results in terms of the immobilization of the hazardous elements using a combined neutralization-adsorption system. The partly-weathered volcanic ash layer acted both as an adsorbent and neutralizer that resulted in the significant decrease in the concentrations of all the hazardous elements in the effluent. The ash sample had a pH of ca. 6 in water so that it was able to raise the effluent $\mathrm{pH}$ around $4-6$. This higher $\mathrm{pH}$ enhanced the precipitation of $\mathrm{Al}$ and $\mathrm{Fe}$ oxyhydroxides/oxides that lowered the concentrations of $\mathrm{As}, \mathrm{Pb}$, $\mathrm{Cu}$ and $\mathrm{Zn}$ in the column effluents (Figures 8 and 10). In addition, the rich $\mathrm{Al}$ and $\mathrm{Fe}$ oxyhydroxides/oxides originally present in the volcanic ash enhanced the adsorption of the toxic elements especially those of $\mathrm{As}, \mathrm{Cu}$ and $\mathrm{Zn}$ (Figures 8 and 10). These results indicate that the combined neutralization-adsorption system is capable of reducing the amount of toxic metalloids and heavy metals released from altered rocks producing acidic leachate and could be utilized as an alternative method for their disposal.

\subsection{Engineering Implications}


Using $\mathrm{CaCO}_{3}$ in powdered form may not be sustainable for the long term stabilization of the altered rock. This is because pyrite oxidation might take decades or even centuries to complete, depending on its relative abundance in the rock. Sufficient amounts of neutralizer are critical to the stability of the $\mathrm{Al}$ and $\mathrm{Fe}$ oxyhydroxide/oxide precipitates and those found in the volcanic ash. Therefore, the kind of neutralizer used must also be able to last as long as oxidizable pyrite is available in the rock. Potential neutralizers for this particular purpose would include limestone, calcite and dolomite. A combination of these "short" (powdered $\mathrm{CaCO}_{3}$ ) and "long" (i.e., limestone, calcite and dolomite) lasting neutralizers might also give better results if utilized. Finally, mixing of the neutralizer and the altered rock would be difficult during the actual disposal of the rock. Thus, other ways of introducing the neutralizer like applying it on the top of the rock or as a "sandwich"-like structure should be considered.

\section{CONCLUSIONS}

This paper describes the mitigation potential of a combined neutralization-adsorption system for excavated altered rocks producing acidic leachate. The findings of this paper are summarized as follows:

(1) Addition of at least $2 \% \mathrm{CaCO}_{3}$ in the batch experiments effectively neutralized the leachate of the altered rock and immobilized most of the As and heavy metals dissolved in it.

(2) The partly-weathered volcanic ash used in this study adsorbed both As and the heavy metals, and the corresponding $K_{F}$ indicates that the ash had adsorption affinity in this order: $\mathrm{As}>\mathrm{Cu}>\mathrm{Pb}>\mathrm{Zn}$.

(3) Addition of $2 \%$ of $\mathrm{CaCO}_{3}$ was insufficient to neutralize the effluent and reduce the concentrations of the toxic elements in the column experiments.

(4) The combined neutralization and adsorption method was more effective in neutralizing the acidic effluent from the rock layer and reducing the concentrations of As and the 
heavy metals than the method using neutralization alone.

(5) The mechanisms of $\mathrm{As}, \mathrm{Pb}, \mathrm{Cu}$ and $\mathrm{Zn}$ release from the altered rock include the dissolution of soluble phases and pyrite oxidation while the immobilization mechanisms of the proposed alternative disposal system include a combination of co-precipitation and adsorption reactions.

\section{ACKNOWLEDGEMENTS}

The authors wish to acknowledge Eco Management Co., Ltd. for the preparation of samples and Horonobe Research Institute for the Subsurface Environment for the mineralogical and chemical analyses of the samples. Part of this research was supported by the Japan Society for the Promotion of Science (JSPS) grants-in-aid for scientific research. Finally, the authors wish to thank the anonymous reviewers for their valuable inputs to this paper.

\section{REFERENCES}

Cornelis, G., Anette-Johnson, C., Van Gerven, T., Vandecasteele, C., 2008. Leaching mechanisms of oxyanionic metalloid and metal species in alkaline solid wastes: A review. Applied Geochemistry 23, 955-976.

De Donato, P., Mustin, C., Benoit, R., Erre, R., 1993. Spatial distribution of iron and sulphur species on the surface of pyrite. Applied Surface Science 68, 81 - 93.

Dixit, S., Hering, J.G., 2003. Comparison of arsenic(V) and arsenic(III) sorption onto iron oxide minerals: Implications for arsenic mobility. Environmental Science and Technology 37, 4182-4189.

Dousova, B., Machovic, V., Kolousek, D., Kovanda, F., Dornicak, V., 2003. Sorption of As (V) species from aqueous solution. Water, Air, \& Soil Pollution 149, 251-267.

Dzombak, D.A., Morel, F.M.M., 1990. Surface Complexation Modeling: Hydrous Ferric Oxide, John Wiley and Sons, New York.

Ghosh, M.M., Teoh, R.S., 1985. Adsorption of arsenic on hydrous aluminum oxide. In: Proceedings of the Seventh Mid-Atlantic Industrial Waste Conference, Lancaster, PA, 139155.

Holmes, P.R., Crundwell, F.K., 2000. The kinetics of the oxidation of pyrite by ferric ions and dissolved oxygen: An electrochemical study. Geochim. Cosmochim. Acta 64, 263-274.

Igarashi, T., Imagawa, H., Uchiyama, H., Asakura, K., 2008. Leaching behavior of arsenic from various rocks by controlling geochemical conditions. Minerals Engineering 21, 191-199. 
Imai, H., 1978. Problem of enargite, luzonite and famantinite, in: Imai, H., (eds.), Geological Studies of Mineral Deposits in Japan and East Asia, University of Tokyo Press, Tokyo, pp. 143-161.

Imai, H., 1999. Mineralizations of base metal deposits of acid-sulfate type coexisting with adularia-sericite type. Resource Geology 49, 147-156.

Katsumi, T., Benson, C.H., Foose, G.J., Kamon, M., 2001. Performance-based design of landfill liners. Engineering Geology 60, 139-148.

Lin, Z., Puls, R.W., 2000. Adsorption, desorption and oxidation of arsenic affected by clay minerals and aging process. Environmental Geology 39(7), 753-759.

Lundgren, T., Soderblom, R., 1985. Clay barriers - a not fully examined possibility. Engineering Geology 21, 201-208.

Malusis, M.A., Shackelford, C.D., Olsen, H.W., 2003. Flow and transport through clay membrane barriers. Engineering Geology 70, 235-248.

McKibben, M.A., Barnes, H.L., 1986. Oxidation of pyrite in low temperature acidic solutions: Rate laws and surface textures. Geochim. Cosmochim. Acta 50, 1509-1520.

Moses, C.O., Herman, J.S., 1991. Pyrite oxidation at circumneutral pH. Geochim. Cosmochim. Acta 55, 471-482.

Moses, C.O., Nordstrom, D.K., Herman, J.S., Mills, A., 1987. Aqueous pyrite oxidation by dissolved oxygen and by ferric iron. Geochem. Cosmochim. Acta 54, 1561-1572.

Nicholson, R.V., Gillham, R.W., Reardon, E.J., 1988. Pyrite oxidation in carbonate-buffered solution: 1. Experimental kinetics. Geochim. Cosmochim. Acta 52, 1077-1085.

Parkhurst, D.L., Appelo, C.A.J., 1999. User's guide to PHREEQC (Version 2) - A computer program for speciation, batch-reactions, one-dimensional transport, and inverse geochemical calculations. U.S. Department of the Interior and U. S. Geological Survey, Denver, CO.

Rapti-Caputo, D., Sdao, F., Masi, S., 2006. Pollution risk assessment based on hydrogeological data and management of solid waste landfills. Engineering Geology 85, 122131.

Schaufuss, A.G., Nesbitt, H.W., Kartio, I., Laajalehto, K., Bancroft, G.M., Szargan, R., 1998. Reactivity of surface chemical states on fractured pyrite. Surface Science 411 (3), 321-328.

Sugimoto, R., 1952. On the geology of the Teine mine, with some remarks on the mineral composition and paragenesis of the Mitsuyama and Koganezawa ore deposits. Jour. Japan. Assoc. Mineral. Petrol. Econ. Geol. 36, $72-84$ (in Japanese).

Tabelin, C.B., Igarashi, T., 2009. Mechanisms of arsenic and lead release from hydrothermally altered rock. Journal of Hazardous Materials 169, 980-990. 
Tabelin, C.B., Igarashi, T., Tamoto, S., 2010. Factors affecting arsenic mobility from hydrothermally altered rock in impoundment-type in situ experiments. Minerals Engineering $23,238-248$.

Tabelin, C.B., Igarashi, T., Takahashi, R., 2012a. Mobilization and speciation of arsenic from hydrothermally altered rock in laboratory column experiments under ambient conditions. Applied Geochemistry 27, 326-342.

Tabelin, C.B., Basri, A.H.M., Igarashi, T., Yoneda, T., 2012b. Removal of arsenic, boron and selenium from excavated rocks by consecutive washing. Water, Air, \& Soil Pollution, doi:10.1007/s11270-012-1181-x.

Todd, E.C., Sherman, D.M., Purton, J.A., 2003. Surface oxidation of pyrite under ambient atmospheric and aqueous ( $\mathrm{pH}=2$ to 10 ) conditions: Electronic structure and mineralogy from X-ray absorption spectroscopy. Geochim. Cosmochim. Acta 67(5), 881-893.

Toscano, G., Caristi, C., Cimino, G., 2008. Sorption of heavy metal from aqueous solution by volcanic ash. Comptes Rendus Chimie 11, 765-771.

Wang, S., Mulligan, C., 2006. Natural attenuation processes for remediation of arsenic contaminated soils and groundwater. Journal of Hazardous Materials 138(3), 459-470.

Watanabe, T., 1936. Study of the reflection microscope of the gold-silver-telluride minerals from Teine mine. Jour. Geol. Soc. Japan 43, 787-799 (in Japanese).

Watanabe, T., 1943. Mode of occurrence of minerals of the enargite group from the Teine mine. Jour. Japan. Assoc. Mineral. Petrol. Econ. Geol. 30, 80-90 (in Japanese).

Watanabe, T., 1944. Mineral paragenesis at the Teine mine. Jour. Geol. Soc. Japan 51, 27-28 (in Japanese).

Wijeyesekera, D.C., O'Connor, K., Salmon, D.E., 2001. Design and performance of a compacted clay barrier through a landfill. Engineering Geology 60, 295-305. 


\section{FIGURE CAPTIONS}

FIGURE 1 A schematic illustration of the combined neutralization-adsorption system.

FIGURE 2 A schematic illustration of the columns used.

FIGURE 3 Leachate $\mathrm{pH}$ as a function of $\mathrm{CaCO}_{3}$ addition.

FIGURE 4 Residual percentages of $\mathrm{As}, \mathrm{Cu}, \mathrm{Pb}$ and $\mathrm{Zn}$ as a function of $\mathrm{pH}$ in batch experiments.

FIGURE 5 Concentrations of $\mathrm{Al}$ and $\mathrm{Fe}$ in the leachate as a function of $\mathrm{pH}$ in batch experiments.

FIGURE 6 Saturation indices of gibbsite $\left(\mathrm{Al}(\mathrm{OH})_{3}\right)$, diaspore $(\mathrm{AlOOH}), \mathrm{Fe}(\mathrm{OH})_{3}$, goethite $(\mathrm{FeOOH})$, malachite $\left(\mathrm{Cu}_{2}(\mathrm{OH})_{2} \mathrm{CO}_{3}\right)$, smithsonite $\left(\mathrm{ZnCO}_{3}\right)$, hydrocerrusite $\left(\mathrm{Pb}_{3}\left(\mathrm{CO}_{2}\right)_{3}(\mathrm{OH})_{2}\right)$ and $\mathrm{Pb}(\mathrm{OH})_{2}$ in batch experiments.

FIGURE 7 Adsorption isotherms of volcanic ash for $\mathrm{As}(\mathrm{V}), \mathrm{Cu}, \mathrm{Pb}$ and $\mathrm{Zn}$.

FIGURE 8 Evolution of the effluent chemistry with time in all cases; (a) pH change with time, (b) As concentration as a function of time, (c) $\mathrm{Pb}$ concentration as a function of time, (d) $\mathrm{Cu}$ concentration as a function of time, (e) $\mathrm{Zn}$ concentration as a function of time, (f) Fe concentration as a function of time, (g) $\mathrm{Al}$ concentration as a function of time and (h) $\mathrm{SO}_{4}{ }^{2-}$ concentration as a function of time.

FIGURE 9 Relationship of $\mathrm{SO}_{4}{ }^{2-}$ to (a) $\mathrm{pH}$, (b) $\mathrm{As}$, (c) $\mathrm{Pb}$, (d) $\mathrm{Cu}$, (e) $\mathrm{Zn}$ and (f) $\mathrm{Fe}$ in the effluents.

FIGURE 10 Saturation indices of gibbsite $\left(\mathrm{Al}(\mathrm{OH})_{3}\right)$, diaspore $(\mathrm{AlOOH}), \mathrm{Fe}(\mathrm{OH})_{3}$, goethite $(\mathrm{FeOOH})$, anglesite $\left(\mathrm{PbSO}_{4}\right)$, gypsum $\left(\mathrm{CaSO}_{4} \cdot 2 \mathrm{H}_{2} \mathrm{O}\right)$ and $\mathrm{Pb}(\mathrm{OH})_{2}$ in the column experiments; (a) case $\mathrm{R}$, (b) case $\mathrm{R}+\mathrm{N} 2$, (c) case $\mathrm{R}+\mathrm{N} 2+\mathrm{A}$. 


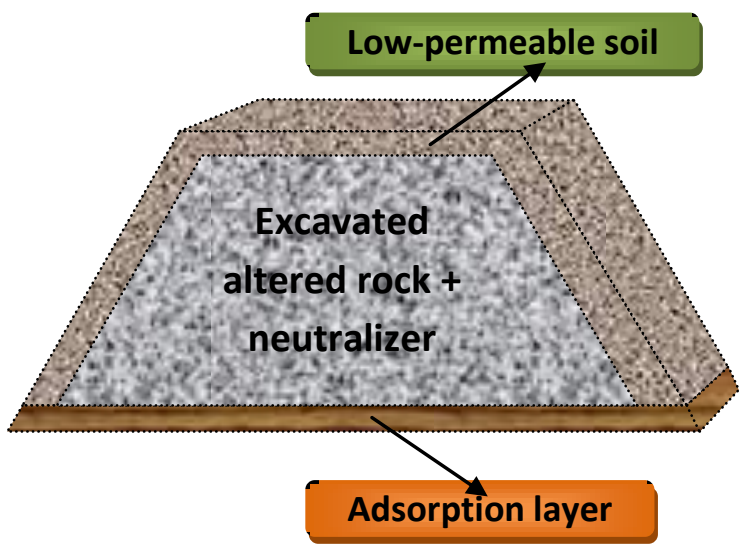

Figure 1

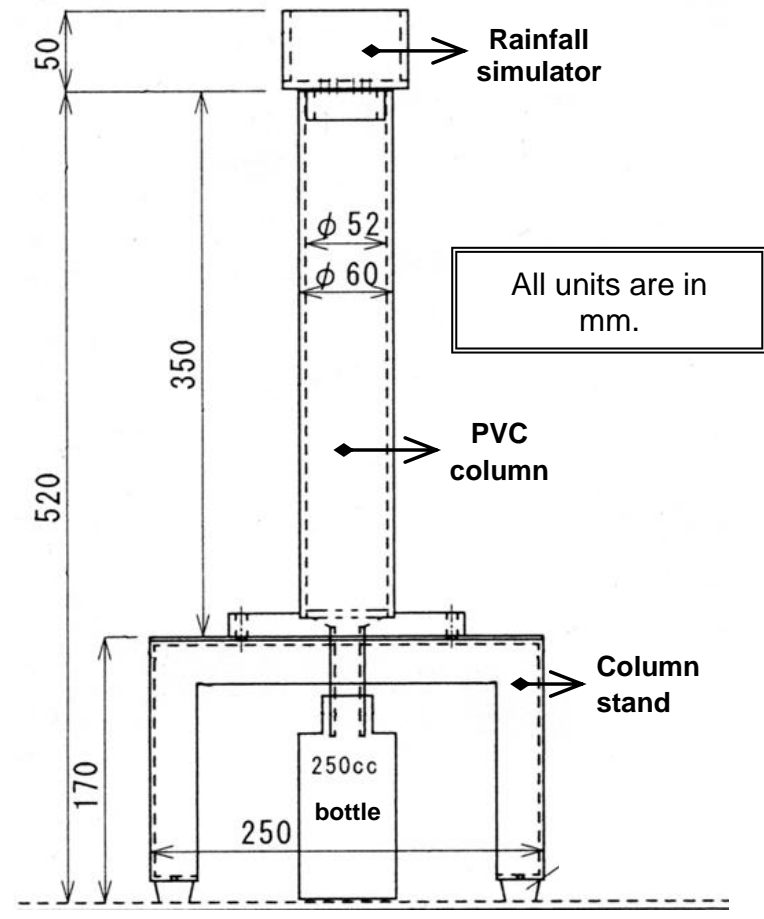

Figure 2 


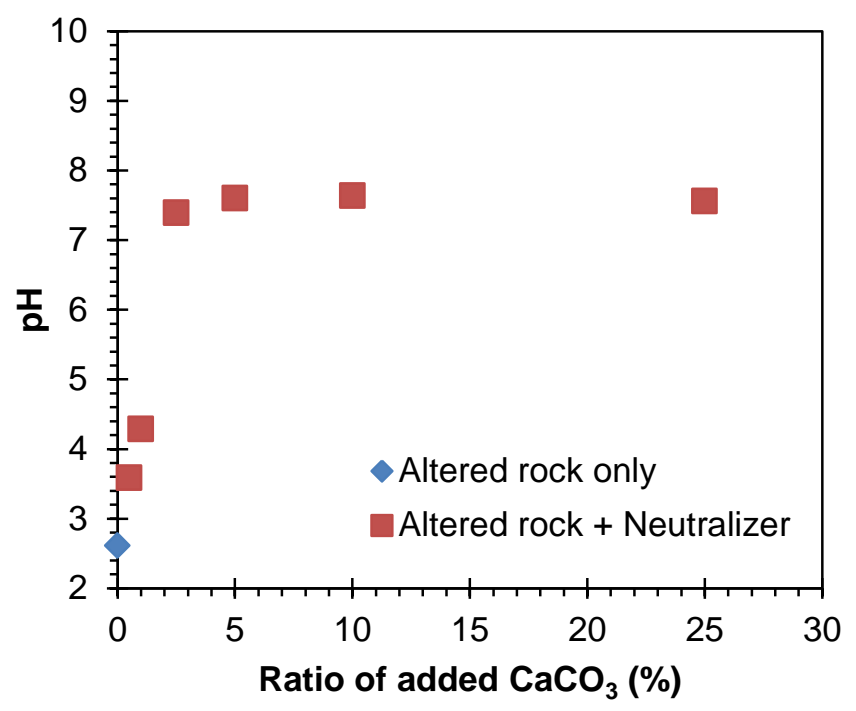

Figure 3

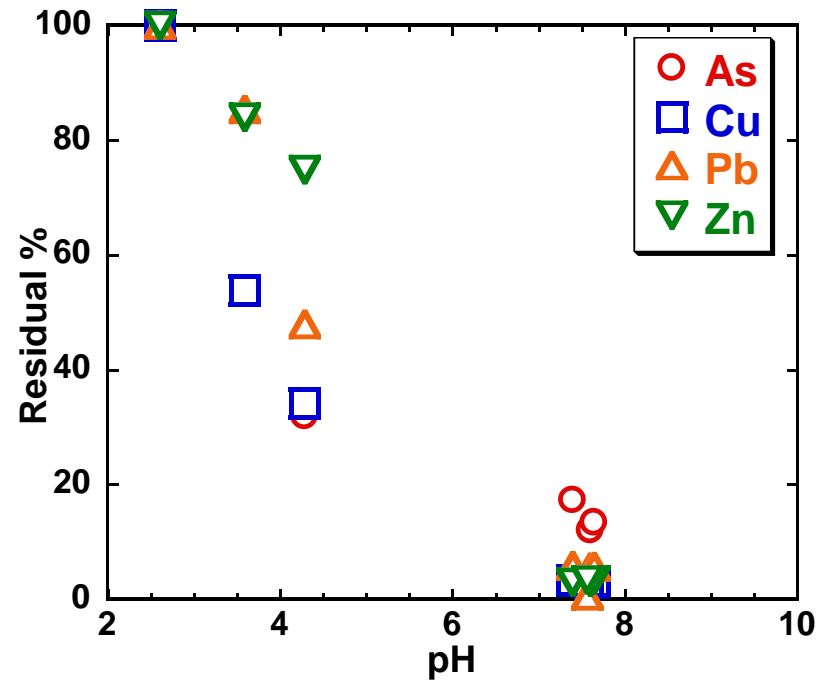

Figure 4 


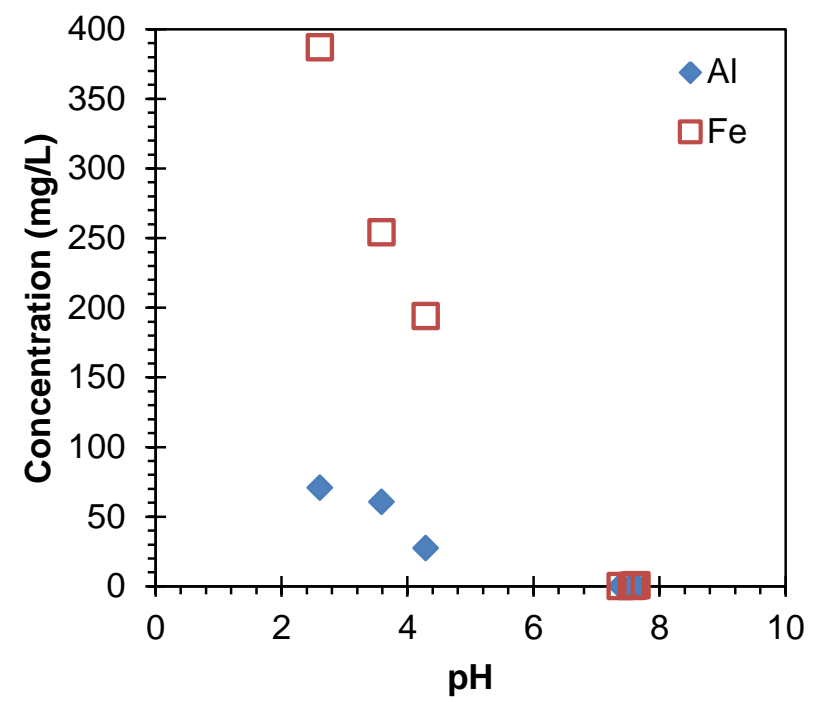

Figure 5

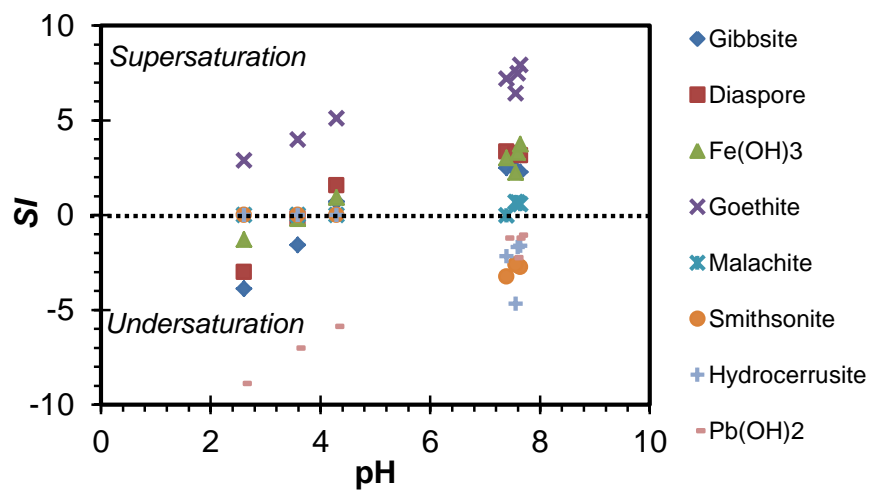

Figure 6 


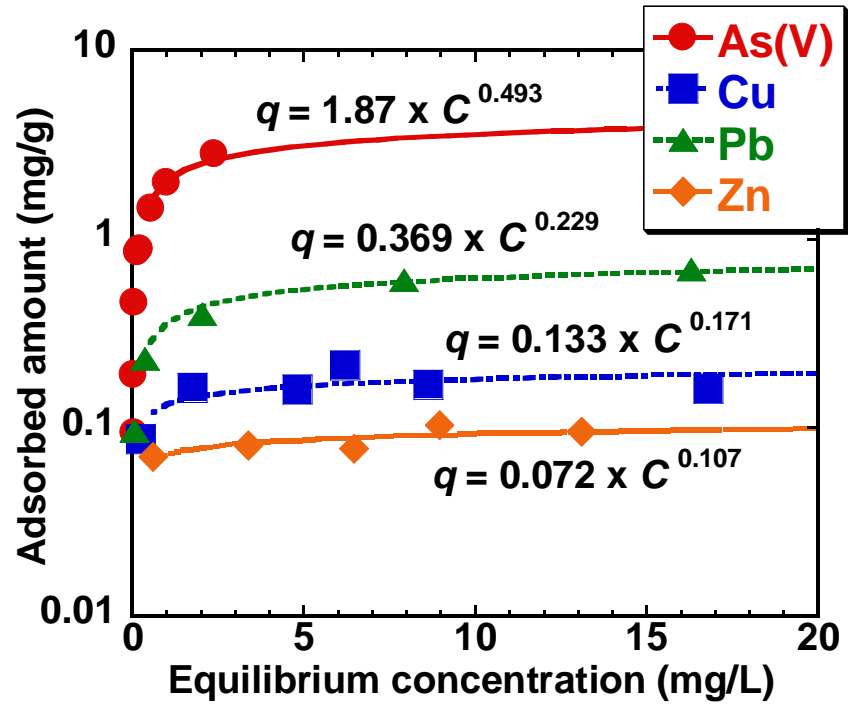

Figure 7 
(a)

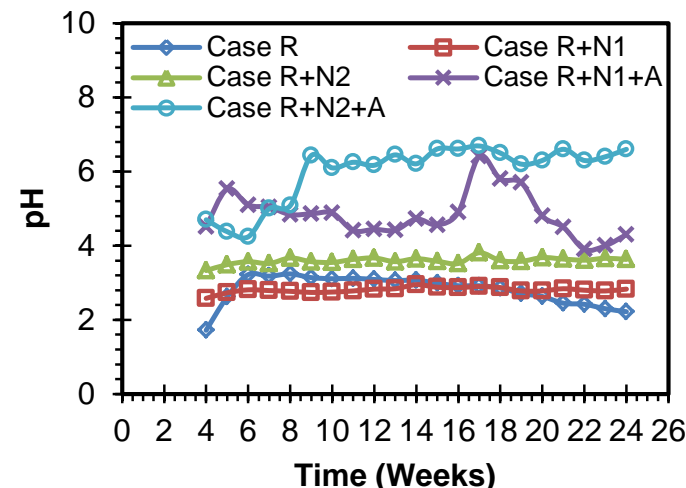

(c)

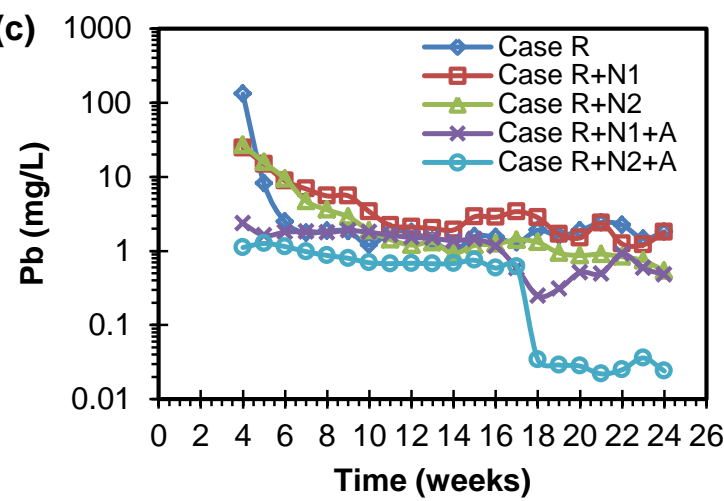

(e)

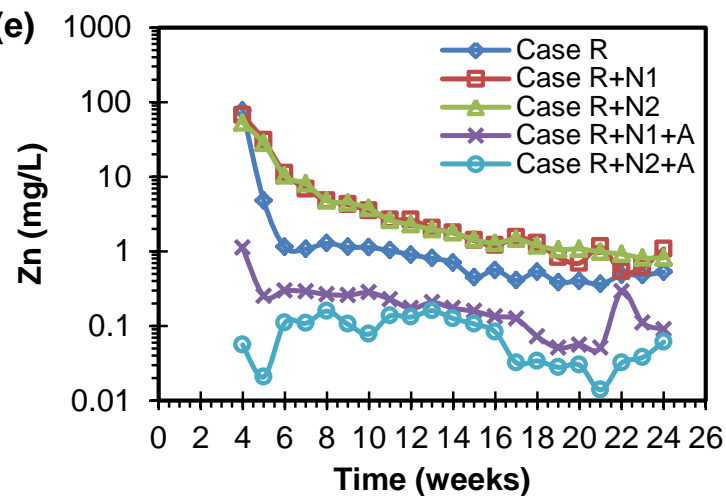

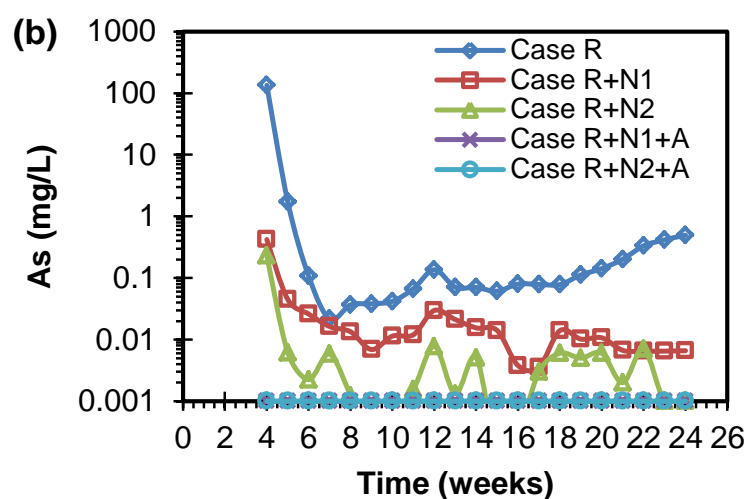
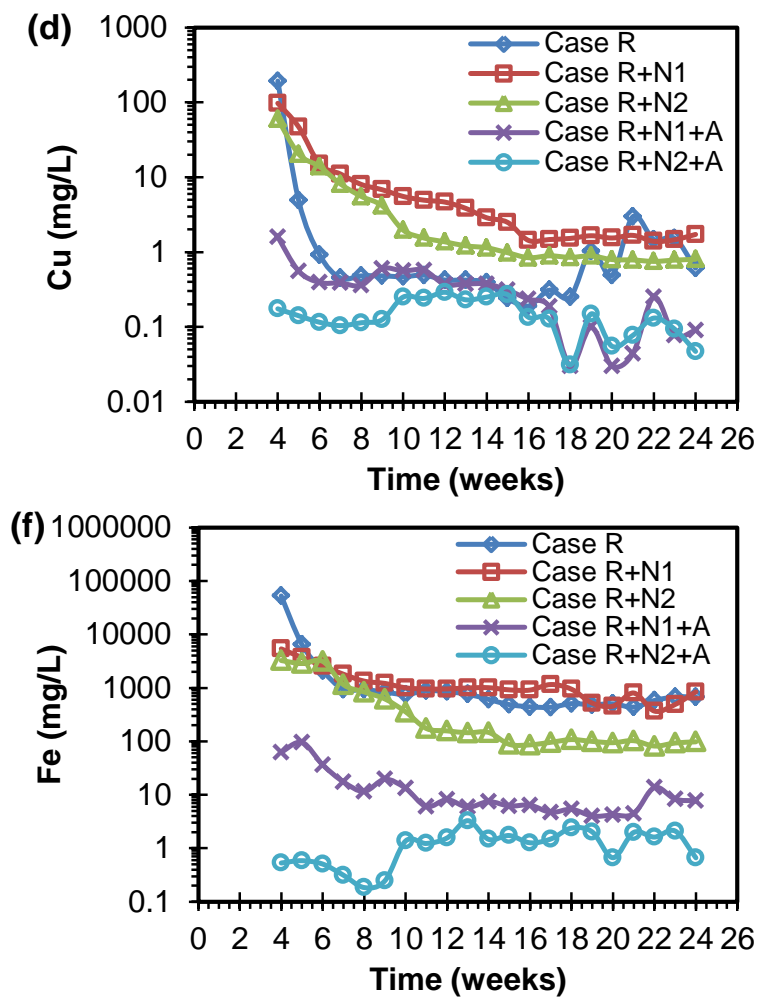

(h)

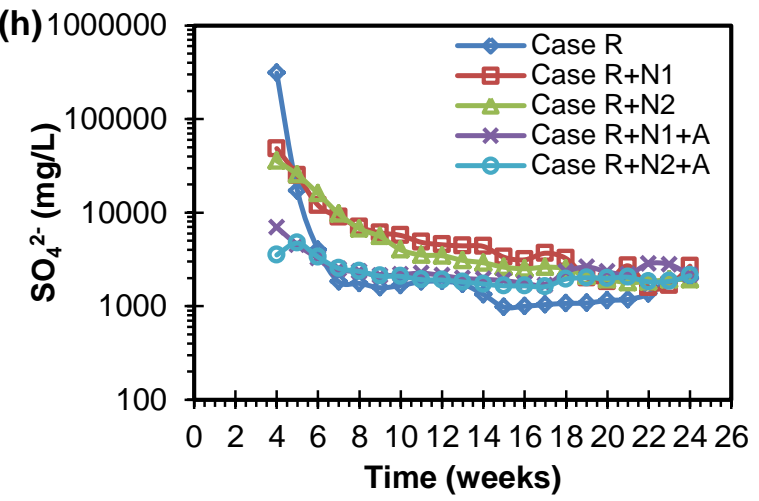

Figure 8 
(a)

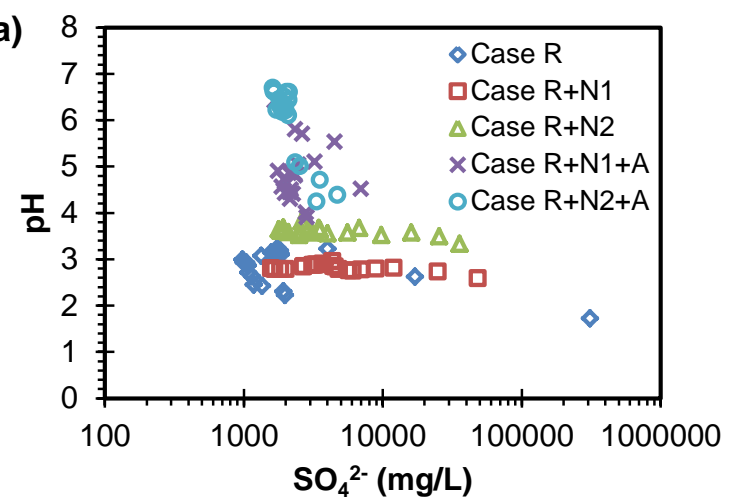

(c)

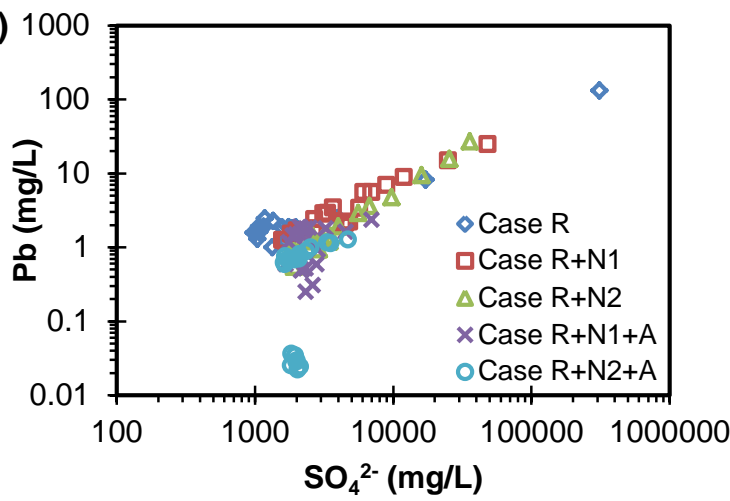

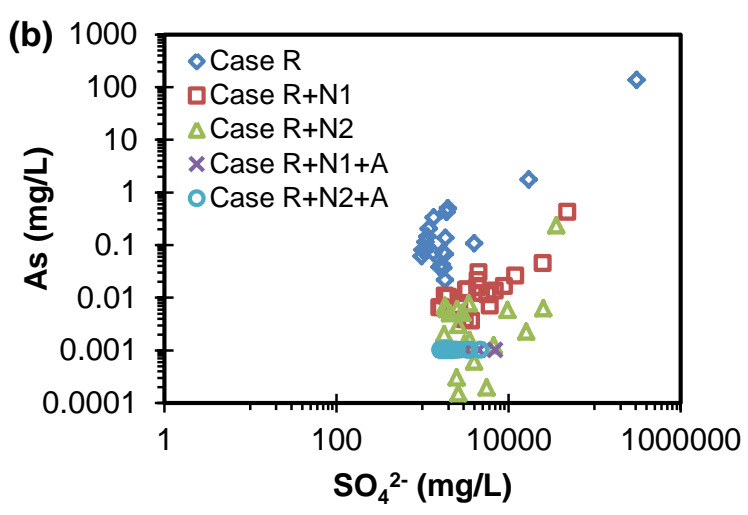
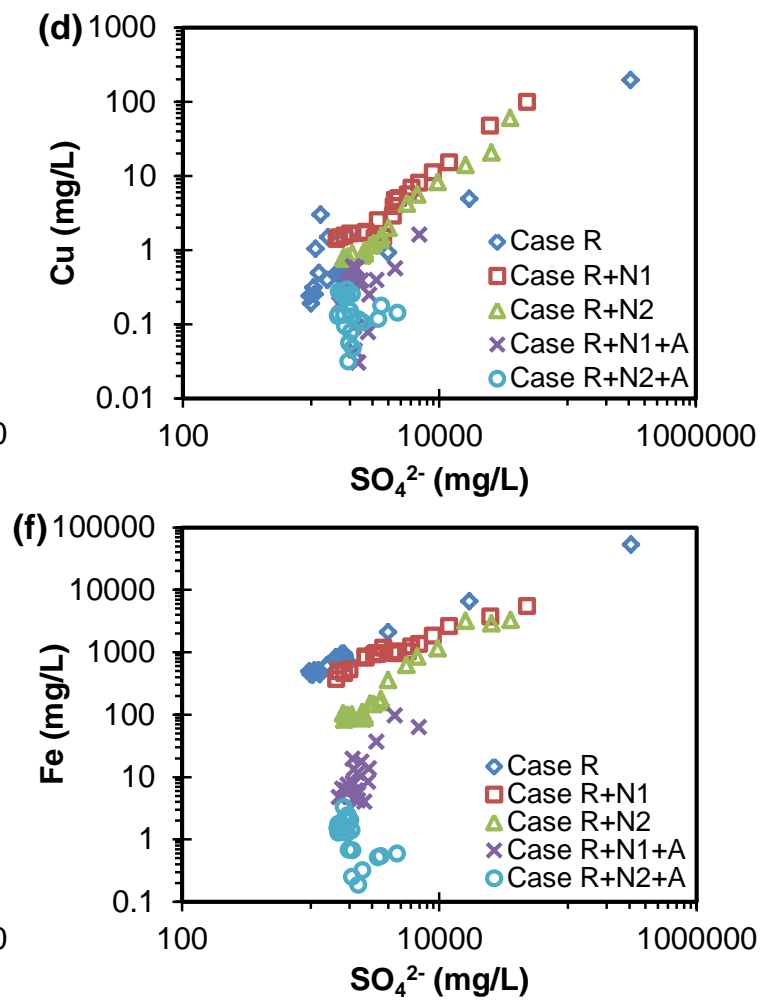

Figure 9 

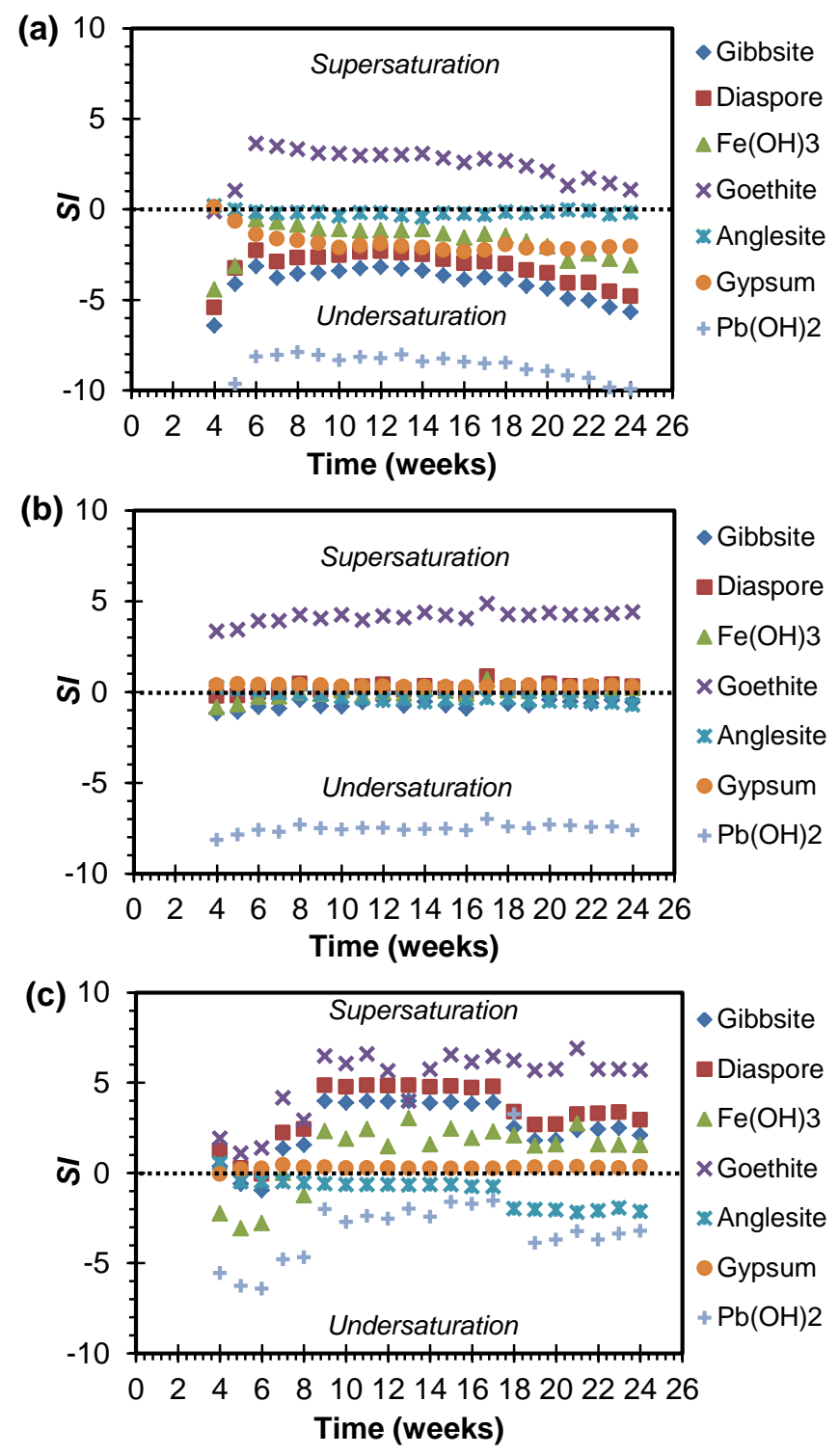

Figure 10 
Table 1. Column experimental conditions

\begin{tabular}{cccc}
\hline \hline Case & $\begin{array}{c}\text { Thickness of } \\
\text { rock bed }(\mathrm{cm})\end{array}$ & $\begin{array}{c}\text { Thickness of } \\
\text { ash layer }(\mathrm{cm})\end{array}$ & $\begin{array}{c}\text { Neutralizer-rock } \\
\text { ratio }(\%)\end{array}$ \\
\hline \hline $\mathrm{R}$ & 20 & 0 & - \\
$\mathrm{R}+\mathrm{N} 1$ & 20 & 0 & 1 \\
$\mathrm{R}+\mathrm{N} 2$ & 20 & 0 & 2 \\
$\mathrm{R}+\mathrm{N} 1+\mathrm{A}$ & 20 & 2 & 1 \\
$\mathrm{R}+\mathrm{N} 2+\mathrm{A}$ & 20 & 2 & 2 \\
\hline \hline
\end{tabular}

Table 2. Chemical compositions of the altered rock and volcanic ash samples used

\begin{tabular}{|c|c|c|c|c|c|c|c|c|c|c|c|c|c|c|}
\hline Sample & $\begin{array}{c}\mathrm{SiO}_{2} \\
\text { (wt. } \% \text { ) }\end{array}$ & $\begin{array}{l}\mathrm{TiO}_{2} \\
\text { (wt. } \% \text { ) }\end{array}$ & $\begin{array}{l}\mathrm{Al}_{2} \mathrm{O}_{3} \\
\text { (wt.\%) }\end{array}$ & $\begin{array}{l}\mathrm{Fe}_{2} \mathrm{O}_{3} \\
\text { (wt.\%) }\end{array}$ & $\begin{array}{l}\mathrm{MnO} \\
(\mathrm{wt} \%)\end{array}$ & $\begin{array}{l}\mathrm{CaO} \\
\text { (wt.\%) }\end{array}$ & $\begin{array}{l}\mathrm{Na}_{2} \mathrm{O} \\
\text { (wt.\%) }\end{array}$ & $\begin{array}{c}\mathrm{K}_{2} \mathrm{O} \\
\text { (wt.\%) }\end{array}$ & $\begin{array}{l}\mathrm{P}_{2} \mathrm{O}_{5} \\
\text { (wt. \%) }\end{array}$ & $\underset{\text { (wt.\%) }}{\mathrm{S}}$ & $\underset{(\mathrm{mg} / \mathrm{kg})}{\mathrm{As}}$ & $\underset{(\mathrm{mg} / \mathrm{kg})}{\mathrm{Pb}}$ & $\underset{(\mathrm{mg} / \mathrm{kg})}{\mathrm{Cu}}$ & $\underset{(\mathrm{mg} / \mathrm{kg})}{\mathrm{Zn}}$ \\
\hline Altered rock & 63.3 & 0.25 & 6.88 & 16 & 0.02 & 0.05 & 0.01 & 0.1 & 0.06 & 10.6 & 150 & 375 & 68 & 62 \\
\hline
\end{tabular}

Table 3. Mineral compositions of the altered rock and volcanic ash samples used

\begin{tabular}{lc}
\hline \hline Sample & Identified minerals \\
\hline \hline Altered rock & Quartz, Pyrite, Kaolinite \\
Volcanic ash & Quartz, Anorthite, Chlorite \\
\hline \hline
\end{tabular}

Table 4. Leachate chemistry of the altered rock

\begin{tabular}{cccccccc}
\hline \hline \multirow{2}{*}{$\mathrm{pH}$} & $\mathrm{Pb}$ & $\mathrm{Cu}$ & $\mathrm{Zn}$ & $\mathrm{Fe}$ & $\mathrm{Al}$ & $\mathrm{Ca}$ & $\mathrm{SO}_{4}{ }^{2-}$ \\
& $\mathrm{As}$ & $\mathrm{Pb}$ & 0.54 & 387 & 70.8 & 4.65 & 1,210 \\
\hline \hline 2.61 & 0.031 & 2.4 & 1.99 & 0.95 &
\end{tabular}

Table 5. Mass balances of $\mathrm{As}, \mathrm{Pb}, \mathrm{Cu}, \mathrm{Zn}, \mathrm{Al}$ and $\mathrm{Fe}$ in case $\mathrm{R}+\mathrm{N} 2+\mathrm{A}$

\begin{tabular}{lcccccc}
\hline \hline & $\begin{array}{c}\mathrm{As} \\
(\mathrm{mg})\end{array}$ & $\begin{array}{c}\mathrm{Pb} \\
(\mathrm{mg})\end{array}$ & $\begin{array}{c}\mathrm{Cu} \\
(\mathrm{mg})\end{array}$ & $\begin{array}{c}\mathrm{Zn} \\
(\mathrm{mg})\end{array}$ & $\begin{array}{c}\mathrm{Al} \\
(\mathrm{mg})\end{array}$ & $\begin{array}{c}\mathrm{Fe} \\
(\mathrm{mg})\end{array}$ \\
\hline \hline Total mass released (rock only) & 10.2 & 11.8 & 15.3 & 6.62 & 686 & 4,898 \\
Mass retained in neutralizer layer (2\% CaCO3) & 10.2 & 8.6 & 12.1 & 1.6 & 333 & 4,330 \\
Mass retained in ash layer & $<0.001$ & 2.62 & 3.05 & 4.93 & 353 & 566 \\
$\begin{array}{l}\text { Total mass released after adding neutralizer and } \\
\text { adsorbent }\end{array}$ & $<0.001$ & 0.501 & 0.139 & 0.073 & 0.926 & 1.2 \\
\hline \hline
\end{tabular}

